\title{
Describing Spaces: Topologies of Interlace in the St Gall Gospels
}

\section{Introduction: Spaces, Pages, Sacred Sites}

The ways in which ideas of the book intersect with notions of space are manifold from Antiquity onwards. As vessels of ideas and knowledge, books and their use invited spatial metaphors based on notions of collecting and storage which were closely bound to the idea of memory. ${ }^{1}$ The notion of the book as space surfaces in metaphors of the book as a garden, library or building throughout the Middle Ages. For Christian writers, notions such as the 'inner library,' the heart as a library of Christ are central, and they pervade patristic texts. ${ }^{2}$ Accordingly, the metaphorical realm of books connects the book and the body, and is not necessarily spatial in a dimensional sense. It goes beyond the specific object of scroll or codex, aiming instead at the texts and their use and reception.

What is striking is that the key mechanism underlying these notions and metaphors, the organisation of individual units into systems that are potentially extendable, is one that found a material and mechanical parallel in the codex format of the book. In contrast to the scroll with its continuous and essentially linear structure, which is only interrupted when it is in use, the codex is both materially and visually divided into units of pages or openings (bifolia) and therefore offers a sequentiality that can be described as stacked and structured a priori. ${ }^{3}$ With the rise of the codex format, spatial notions became potentially applicable to an understanding not only of the conceptual, but also of the material dimension of the book.

It is this last aspect that has interested art historians most. The metaphorical-material parallel suggests that those involved in constructing a manuscript, scribes and illuminators, may have drawn on the notion of the book as a space, and that therefore analysing text, image and ornament can in turn contribute to our understanding of medieval concepts of space.

As sacred scripture, liturgical objects and occasionally as venerated relics, books could also be involved in the construction of (sacred) space. In early medieval Lindisfarne, the book of St Cuthbert, maybe identifiable as the Lindisfarne Gospels, was the focus of the community on the high altar, and liturgical books generally created

1 Carruthers 2008, esp. 37-55 and 274-337.

2 See, for example, Jerome's description of the young priest Nepotianus, who by reading has made "his breast a library of Christ” (pectus suum bibliothecam fecerat Christi): S. Hieronimi Presbyteri 1845, col. 595.

3 For a more detailed analysis of this contrast, see Reudenbach 2009, esp. 59-61.

Ә Open Access. () 2019 Tina Bawden, publiziert von De Gruyter. (c) BY-NC-ND Dieses Werk ist lizenziert unter der Creative Commons Attribution-NonCommercial-NoDerivatives 4.0 Lizenz.

https://doi.org/10.1515/9783110629156-002 
communal spaces by acting as "spatial foci of veneration and of gatherings for worship." "For sacred scripture, biblical books such as the gospel book I will discuss, the sacred text was housed in a material codex in a way that was similarly complex in theological construction as the intersection between material architecture and the divine realm in church buildings conceived as sacred spaces. While controversies over church buildings and rights of sanctuary give an indication of early medieval notions of sacred space, ${ }^{5}$ conceptualisations of the book as a sacred space remain more elusive. This paper explores the graphic principles that could be employed in the production and decoration of one particular type of book, the gospel book, in order to present it as an organised system that can be described in spatial terms. Following a discussion of the architectural forms that have influenced scholarly interpretation first and foremost, I consider the Irish gospel book St Gallen 51 a case study which suggests an alternative structuring principle, that of interlace.

\section{Gospel Book Approaches}

One type of book in particular has been referred to as a sacred space, and that is the gospel book. In early medieval gospel books, the fourfold structure of sacred scripture in the gospel texts is the central theme, generally resulting in highly planned and structured manuscripts. Aside from the four texts by the Evangelists, gospel books typically include a variety of additional textual material. These texts are referred to as prefatory or preliminary material because of their typical position at the beginning of the book, and for their explanatory character relative to the content and genesis of the Vulgate version of gospels. ${ }^{6}$ Prefatory material can comprise any or several of the following elements: a set of canon tables, ${ }^{7}$ the letters and explanatory material that went with both this Eusebian system and Jerome's Vulgate, ${ }^{8}$ concordances and chapter lists. ${ }^{9}$ The programme of decoration of gospel books is more standardised than that of any other book type of such central importance in the early Middle Ages. In a similar

4 Brown 2007, 45; Brown 2002.

5 See the comprehensive discussion of the concept of sacred space in the early Middle Ages in two recent monographs: Collins 2012; Czock 2012.

6 De Bruyne 1920. For the period concerned in this article: McGurk 1961, esp. 110-113.

7 Canon tables are the index of gospel passages developed by Eusebius of Caesarea in the fourth century as a means to cross-reference sections recorded by more than one Evangelist, which Jerome included as a preface to his Vulgate gospels in the late fourth-century, thereby guaranteeing their distribution in the West.

8 Known by their first words as Novum Opus (letter Jerome to Pope Damasus), Sciendum etiam (instructions for the use of the canon tables), Plures fuisse (remarks on the fourfold gospel), EusebiusCarpianus (letter Eusebius to Carpianus).

9 Chapter lists for each of the four gospels (breves causae), gospel prefaces (argumenta), the capitula lectionum for liturgical use. 
way to the prefatory and explanatory text material, which centres on the genesis of this text and the representation of a harmonious relationship between the four gospels, the pictorial tradition likewise brought forth representations of the gospel harmony, iconographic inventions such as the four-symbol page of Insular art, which combines the four symbols of the Evangelists, man, lion, ox and eagle, ${ }^{10}$ the Majestas Domini, ${ }^{11}$ the Tetramorph, or author portraits of the four combined Evangelists as scribes more usual on the Continent. ${ }^{12}$ In addition, by means of repetition, variation and alternation of graphic and/or figural aspects, the illumination of pages relating to the gospel texts-evangelist portraits, incipit and initial pages-could also aim at a visualisation of harmony. Techniques employed to this end comprise numerological, geometrical, graphic, diagrammatic, ornamental and representational elements and formats, of which some have captured scholarly interest more than others.

The visual format which has attracted most attention from scholars is the sequence of canon tables. It seems that from their conception onwards canon tables were presented in architectural frames, using colonnades and arches to subdivide the sections. Scholars have argued that the fact that the conception of the canon tables by Eusebius is almost contemporary with their architectural rendering in the earliest extant gospel books is significant. It was Carl Nordenfalk who first suggested that the gospel book in particular from its beginnings was conceived as a sacred space, and that the canon tables prepare the encounter with Holy Scripture by providing "a propyleum through which we approach the sanctum sanctorum of Holy Writ."13 Exploring this idea further with regard to early medieval examples, Bruno Reudenbach has argued that the canon tables function in two ways: as a coherent, often symmetrical structural unit on one page, they visualise the harmony of the gospel texts and the unity of the Word of God; by forming a sequence over several pages, they reference generalised spaces, such as the colonnades and arches of a church of the basilica type, and give someone turning the pages an impression of moving through a space. ${ }^{14}$ For Insular gospel books, Carol Neuman de Vegvar has explored the possibility that the pictorial architecture can refer to a specific space such as the Holy Sepulchre complex, known through pilgrimage accounts, in order to imbue the entrance into the gospel text with further meaning. ${ }^{15}$ At the same time as displaying a particularly broad variety of ornamentation, she observes that "the number of

10 E. g. Trier Gospels from Echternach (Trier, Domschatz, MS 61, fol.1v); Book of Armagh (Dublin, Trinity College MS 52, fol.32v); Book of Kells (Dublin, Trinity College Library, MS A.1.6 (58), fol. 290v). 11 On the Majestas Domini in Carolingian manuscript illumination, see most recently Kessler 2015.

12 For example in the Aachen Gospels ("Schatzkammer-Evangeliar": Aachen, Domschatz, Inv.-Nr. 4, fol.14v) or the First Bible of Charles the Bald from Tours: Paris, Bibliothèque nationale, MS lat. 1, fol. 329v.

13 Nordenfalk 1982, 30. In his earlier monograph, Nordenfalk had argued that the arcades as frames compensate for their lack of sacred status as compared to the gospel texts: Nordenfalk 1938, 125.

14 Reudenbach 2009, esp. 65.

15 Neuman de Vegvar 2007. On Insular manuscripts, see also: Mullins, Elizabeth (2001), The Insular 
intercolumniations [...] in the Insular examples is generally, though not universally, set at a total of four or three."16 This rule seems to have been adhered to even if it results in having an empty arcade, and she suggests it was therefore probably semantically charged, with notable parallels to representations of the Edicule and the Anastasis Rotunda. ${ }^{17}$

The interpretation of sacred scripture as sacred space made accessible through and in the gospel book, therefore, has been bound significantly to the analysis of the pictorial repertoire of canon tables, and aided by their use of architectural forms. Inconsequential for liturgical purposes, and therefore hardly of any practical use at all, the functions of canon tables lie firmly in the visual realm. ${ }^{18}$ They provide an image of the ordering of the four gospels with a combination of diagrammatic, ornamental and representational forms, expressing gospel harmony and presenting a numerical overview over texts that themselves follow a linear arrangement. While no doubt the authority of textual tradition and the practice of exemplars ensured that the canon tables were maintained as part of gospel books throughout the Middle Ages, in principle and practice their main visual function of conveying the interrelationships of the fourfold gospel could be partly or fully transferred to other elements of gospel book decoration. This is also true of their entrance function inferred from the typical placement at the beginning of the book, and scholars have argued that carpet pages and incipit or initial pages in Insular books served similar functions. Victor Elbern concludes this from a comparison of their design with stonework in early churches, and argues that carpet pages and incipit pages in Insular manuscripts perform the same function within the space of the book as early Christian cancelli within the church space, that is, they have liminal character, marking a boundary at the same time as offering an invitation to enter the space beyond. ${ }^{19}$ By availing themselves of the same vocabulary of forms, Elbern argues, book illuminators were able to draw on architectural settings in order to heighten the experience of sacred scripture.

Both scholarship on the canon tables and Elbern's interpretation ultimately focuse on architecture and more specifically an entrance situation in order to explain prefatory material with regard to content of the gospels and position in the material gospel book. The question that remains open for discussion is how central architectural space is-whether it is represented, referenced or evoked-for an understanding of gospel books as sacred spaces. Are there other methods employed by early medieval

Reception of the Eusebian Canon Tables: Exegesis and Iconography, $\mathrm{PhD}$ thesis, University College Cork. As it remains unpublished, I have not been able to consult this work.

16 Neuman de Vegvar 2007, 244.

17 Like Reudenbach, Neuman de Vegvar also explores the connection with movement through these spaces as described by pilgrims: Neuman de Vegvar 2007, 251.

18 Reudenbach 2015, esp. 356.

19 Elbern 1971. 
producers of gospel books to express this notion? I would like to explore this idea with regard to the principle of interlace.

\section{Interlace}

As ornament, interlace is widely used in early Insular manuscripts, metalwork and sculpture. Related to early cultural techniques such as basketry, netting and matting, the act of interlacing several strands is something that makes use of three dimensions, at the same time as the pattern achieved is surface-oriented. As opposed to the textile technique of combining a number of materially separate and diverse threads or strands, pleating or weaving, the uses of interlace in the Insular visual arts, in stone, metalwork and manuscript illumination capitalise on surface pattern in their templates and designs. The constructional steps used to create interlace make this very clear, and they often remain visible in manuscripts underneath the finished ornament or on the reverse of the page, with breaks or hole points laid out on a grid, pricked or laid out in drypoint or ink, and sometimes lines drawn freehand or with the aid of a straight-edge. ${ }^{20}$ Complex interlace patterns and their conceptual prerequisites reveal a thorough command of constructional thinking. They point to the ornament's function as a cognitive exercise for maker and viewer, while at the same time plotting the actual pattern could be an easy task for someone practised. It is, however, not the ornamental motif which interests me here, but the visual or aesthetic principle of interweaving or interlacing and its effects on an understanding of structure, perception, and meaning within the gospel book.

Like the ornamental motif, interlace as a principle has been discussed in various different contexts. In 1993, Ernst Kitzinger referred to interlacing as "a basic tendency in Hiberno-Saxon art." ${ }^{21}$ He concludes that "in early Insular art such designs clearly were a matter of preference and aesthetic delight, but they did have a magic potential and there are cases in which their potency was meant to become operative. It all depends on the context." 22 This context, according to Kitzinger, is provided more often in items of personal armour, and sometimes in architectural sculpture, than it is in book illumination, where interlace is used too accumulatively to be explained fully as apotropaic device. ${ }^{23}$ The movement of interlacing and the resulting stylistic structure has been seen as an aesthetic choice that pervades visual art and texts from the British

20 On the typology of interlace, see Cramp 1991, 28-45.

21 Kitzinger 1993, 4. John Leyerle even states that "the seventh and eighth centuries might justly be known as the interlace period": Leyerle 1967, 3.

22 Kitzinger 1993, 6.

23 This is the conclusion drawn from the example of the carpet pages in the Lindisfarne Gospels: Kitzinger 1993, $3 f$. 
Isles alike. In the context of scholarly interest in the relationship between text and image in the second half of the $20^{\text {th }}$ century, Old English poems such as The Wanderer or Beowulf were described as "literary work parallel to the carpet pages of the Lindisfarne Gospels," or "like one of the great signature pages of the Book of Kells." ${ }^{24}$ Most recently even considered as a phenomenon guiding cultural integration in the early medieval British Isles, the interlace principle seems ubiquitous, though its power as aesthetic or structural principle is watered down in these broad contexts. ${ }^{25}$ The perceptual and cognitive task of understanding interlace patterns, which can easily be taken in as a whole but reveal the intricacy of their designs only when following individual strands, can also be linked to the Insular riddling culture, where the solution of a riddle is often known from the start, shifting aesthetic delight not to recognition, but to the detection and pursuit of the route of thought that leads there.

In spatial terms, we might therefore consider looking at two ways of moving through the space of sacred scripture: There is the goal-oriented approach and revelation implicit in seeing the canon tables as an entrance, a way of moving closer to the inner sanctum in agreement with the concentric arrangement of sacred spaces, and there is meditative movement through and around a space connected to ideas not of entrance, but dwelling and meditation, focusing on relational rather than hierarchical aspects of space.

\section{St Gallen, Stiftsbibliothek, Cod. 51}

The Gospel book in the Stiftsbibliothek in St Gallen, Codex Sangallensis 51, is the most lavish manuscript to attest to the Irish ties of that monastic foundation. ${ }^{26}$ It was probably produced in the Irish midlands around the middle of the eighth century. ${ }^{27}$ The manuscript is complete and well-preserved; it contains the four gospel texts and a comparatively high number of fully illuminated pages. ${ }^{28}$ Both the first and the last opening are fully decorated, indicating that the illumination is central to a

24 Leyerle 1967, 7; Huppé 1970, 26.

25 Beall 2010.

26 Sankt Gallen, Stiftsbibliothek, Cod. 51, 295 ×215/220 mm, 12 quires, paginated. Duft/Meyer 1956, 69-71; Lowe 1956, no. 901, 20; McGurk 1961, no. 117, 97 f.; Alexander 1978, cat. no. 44. Digital facsimile: http://www.e-codices.unifr.ch/en/list/one/csg/0051. A concise overview over the manuscript's scholarly historiography of dating and localisation (Ireland or an Irish scribe on the Continent), as well as a characterisation of the biblical text and its relation to the Vulgate is given by McNamara 2001, esp. 191-194.

27 The most recent contribution asserts the Irish provenance on palaeographical and codicological grounds: Joseph Flahive, who has prepared a facsimile with commentary on the St Gallen Gospels to be published in 2018, concludes that it "was written in the Irish midlands, probably in the church of Lorrha, Co. Tipperary, ca. 750-60 A. D.”: personal correspondence, May 2015.

28 The commentary volume of the forthcoming facsimile will contain an essay on the illuminations by the late Jennifer O'Reilly. The date of publication of the present volume means that I have not been 
comprehension of the manuscript's ordering. The further eight illuminated pages are also consistently arranged in pairs across openings. The strive to keep blank parchment and singletons to a minimum is evident in the physical structure, as is the need to resort to parchment of varied quality: Towards the end of the manuscript, leaves vary greatly in thickness, size and colour, and the amount of holes increases. Taking these special requirements and obstacles into account, the homogeneous appearance of the codex in script and image is a real achievement of planning and execution, enabled by a certain amount of flexibility of the scribe. The important breaks between gospel texts show that the number of lines can vary, and the size of script was adjusted according to need, for example at the end of Matthew (p. 77), where the last words (Mat. 28, 20) have been squeezed in just below the last line. ${ }^{29}$ At the same time, the arrangement of the illuminated pages indicates that the opening trumps the page as the aesthetic unit.

Containing no prefatory material, the first opening of the book begins with the portrait of Matthew and the first words of Matthew's gospel, Liber generationis Ihesu (Fig.1). The following opening is reserved for the genealogy of Christ. The series of Christ's Old Testament ancestors follows a repetitive formula, “A autem genuit B; $B$ autem genuit C; ...” (Fig. 2). While this generally ensures a regular visual appearance of the text on the page in gospel books, the scribe in the St Gall Gospels has gone one step further: Names and words are split and spaced out in such a way that they form six rough columns on the left, and five columns on the right, connected on the ruled lines by scrolling in red.

In specifically Insular tradition, the mention of Christ's name at Matthew 1,18 is awarded an opening of its own, with the only carpet page of the manuscript facing it on the left (Fig.3). The first two letters of the name Christ are rendered in the Greek letters Chi and Rho on the right. The nomen sacrum functions as a second opening for the gospel of Matthew. As Jennifer O'Reilly has pointed out, the genealogy of Christ from Matthew 1,1-17 was treated as a separate book by Hiberno-Latin Matthean commentaries, and could also be awarded this status within Insular gospel books. ${ }^{30}$

able to consult her latest contribution, and therefore take into account Jennifer O'Reilly's analysis of St Gallen 51 as published in earlier articles: O’Reilly 2011, esp. 198-202; O'Reilly 2013, esp. 64-70.

29 Six lines remain empty at the end of Mark, p. 77, so the scribe has added finit hic liber in the centre of the remaining space on the page; the page preceding the opening for John, p. 207, is the only one that is empty except for the last words of Luke's gospel (semper in templo laudantes et benedicentes deum) which do not follow the rulings and are not placed at the top of the page as a continuation from p. 206, but have the layout and abbreviating flourishes of a separate invocation. The final chapter of John's gospel stops short at verse 24 despite several lines on the page remaining, and the rest has been added in a Carolingian hand. This scribe also added amen amen dignus est operarius mercede sua (cf. Luke 10,7, "the labourer is worthy of his hire").

30 O’Reilly 1998, 76-78, with reference to Ailerán’s Interpretatio mystica progenitorum Christi, and Hiberno-Latin commentaries in the manuscripts Orléans, Bibliothèque municipale MS 65 (62) and München, Bayerische Staatsbibliothek MS Clm 6233. 


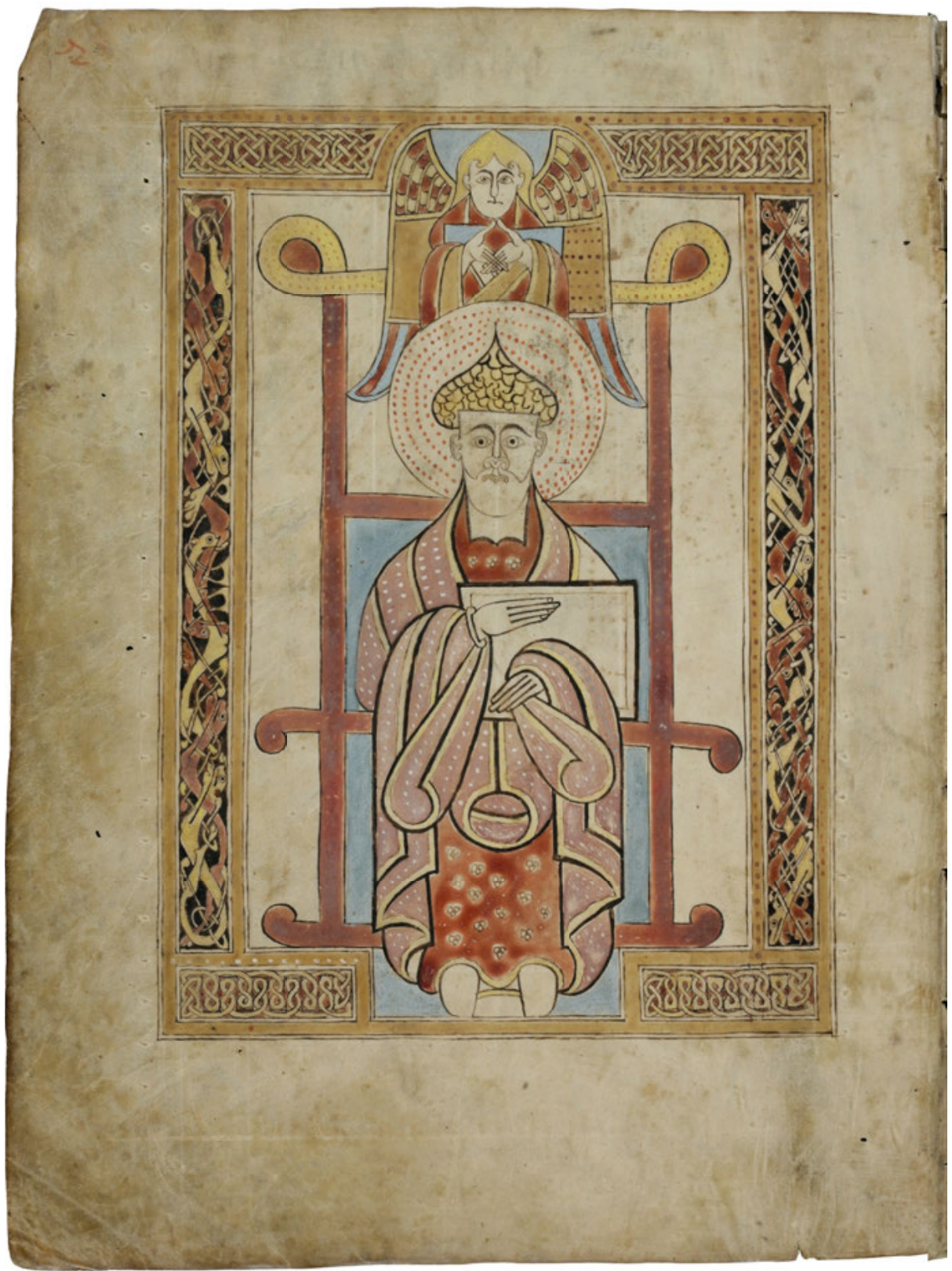




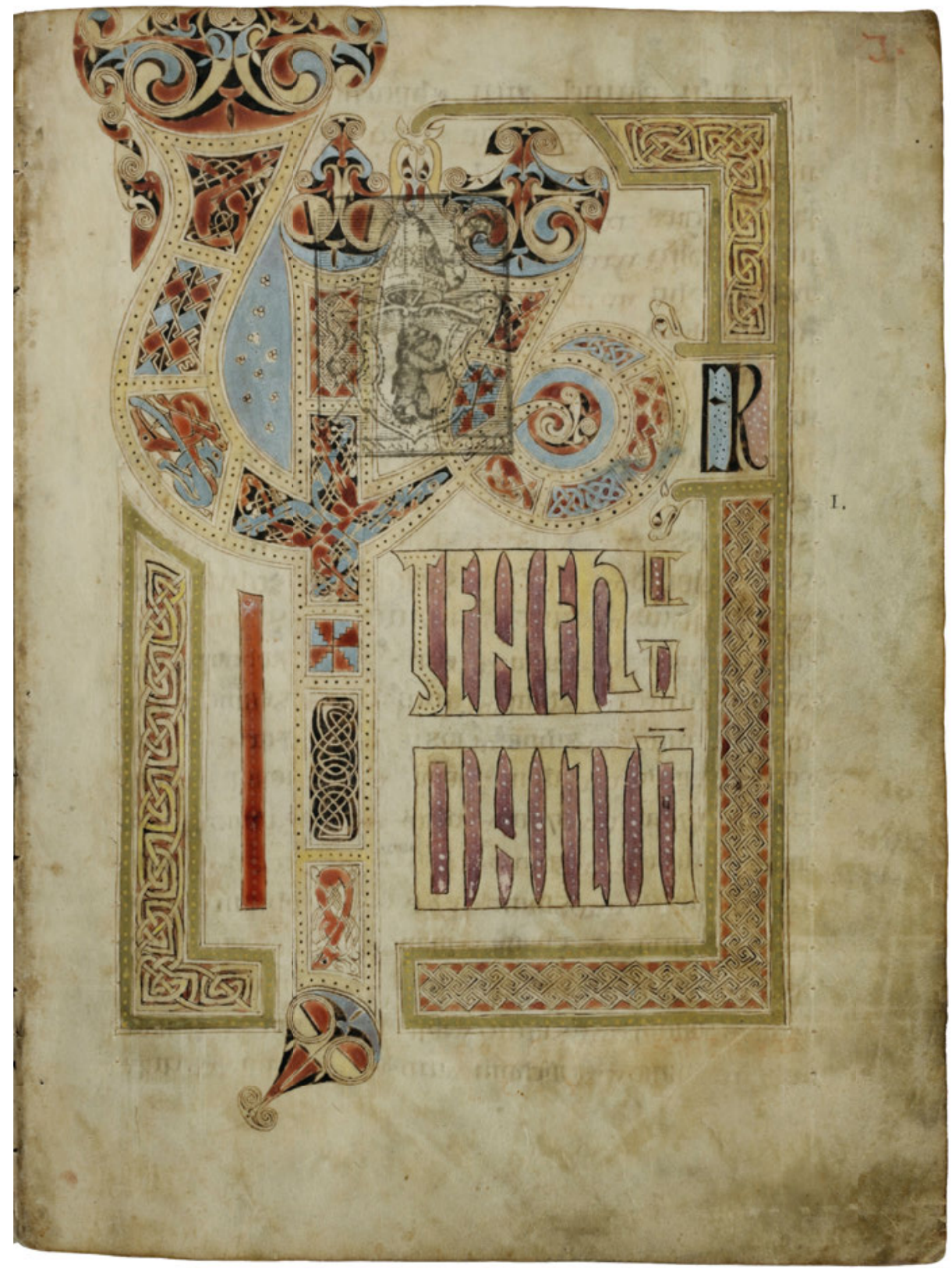

Fig. 1 (both pages): Opening for St Matthew's gospel, St Gall Gospels, Ireland, mid-eighth century. St Gallen, Stiftsbibliothek, MS 51, pp. 2-3. 
$x \bar{p}$ FiGi dauid piur abrachan abracham. aucen senur ya issac issar am tuam ré

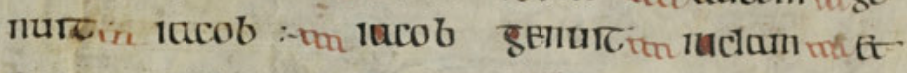

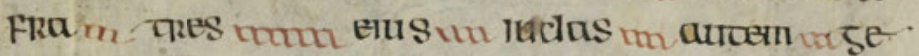

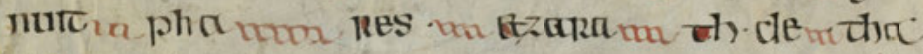

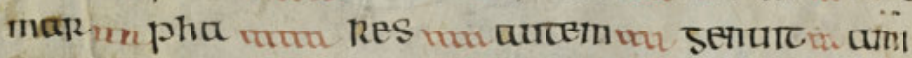

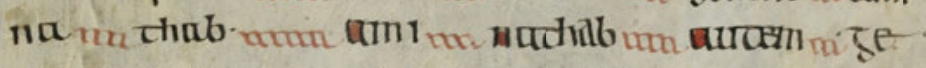

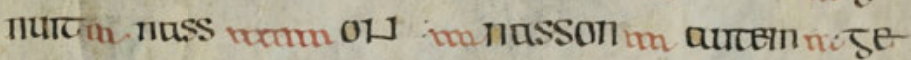

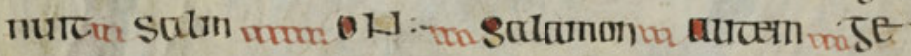

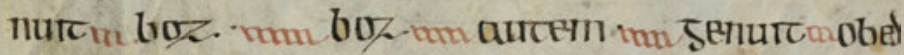

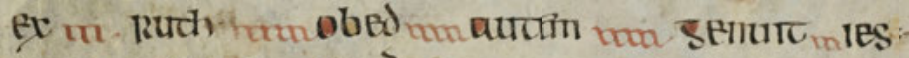

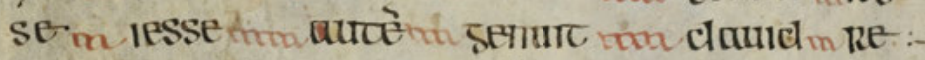

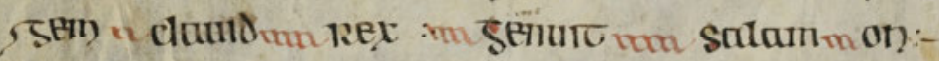

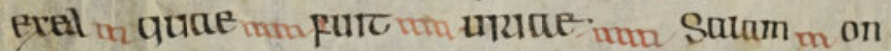

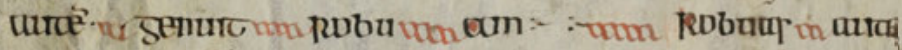

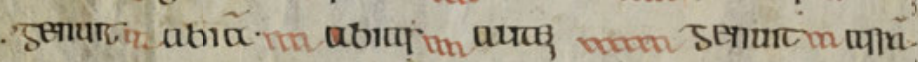

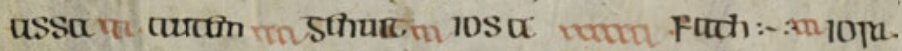

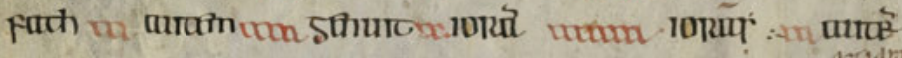

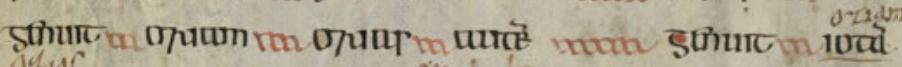

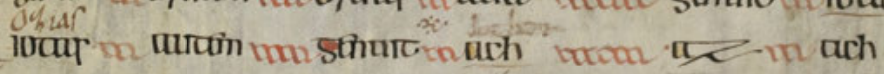

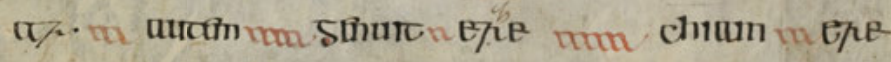

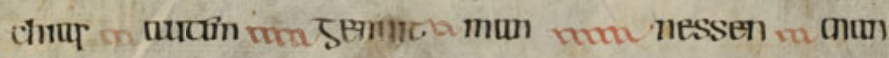
nus un Sesh tom SHut bun mon mon : an um

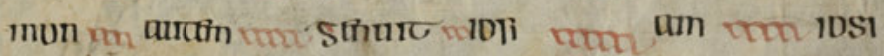

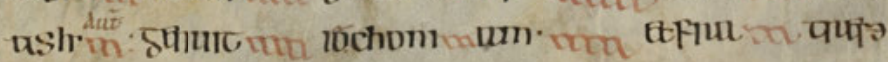


mctumsmistumaonem babitonis tepose quansmismuquon

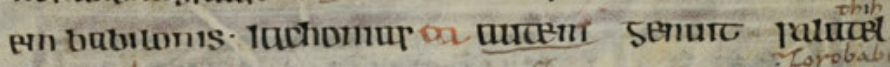

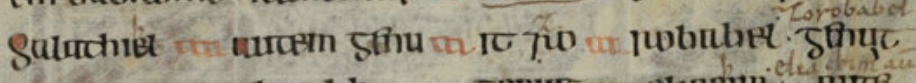

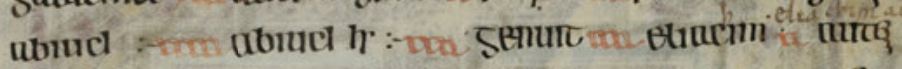

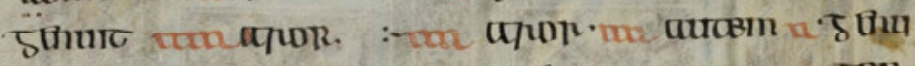

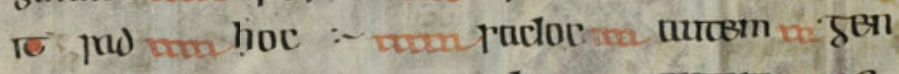

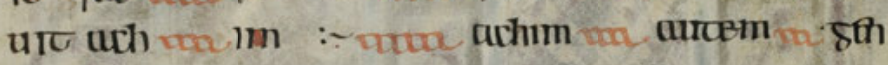

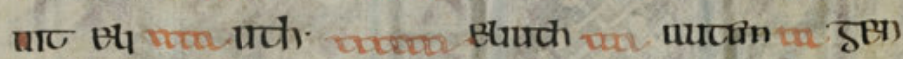

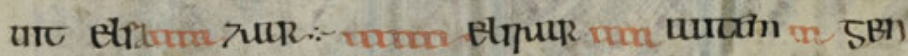

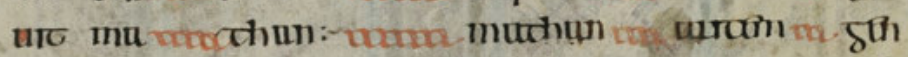

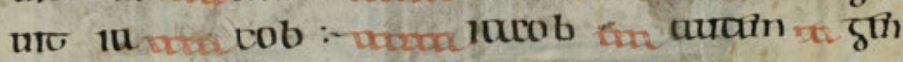

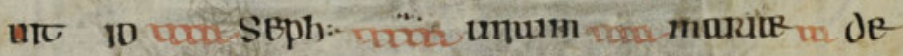

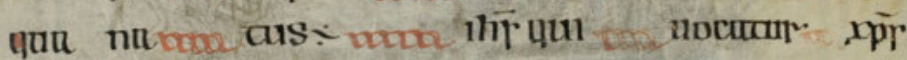

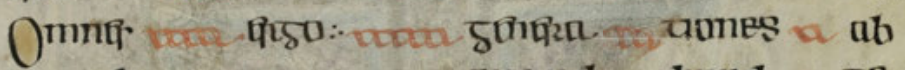

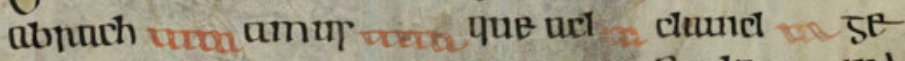

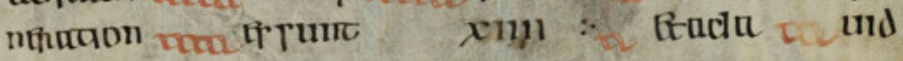

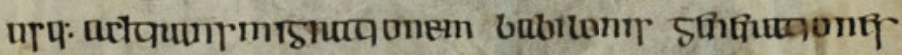

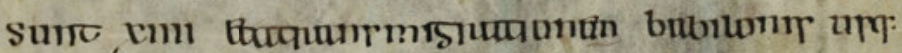

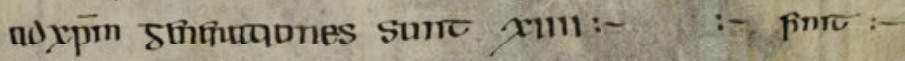

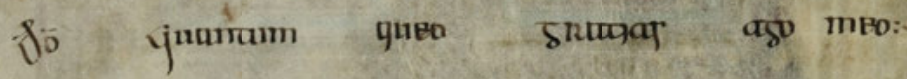

Fig. 2 (both pages): Opening with the genealogy of Christ, St Gall Gospels, Ireland, mid-eighth century. St Gallen, Stiftsbibliothek, MS 51, pp.4-5. 


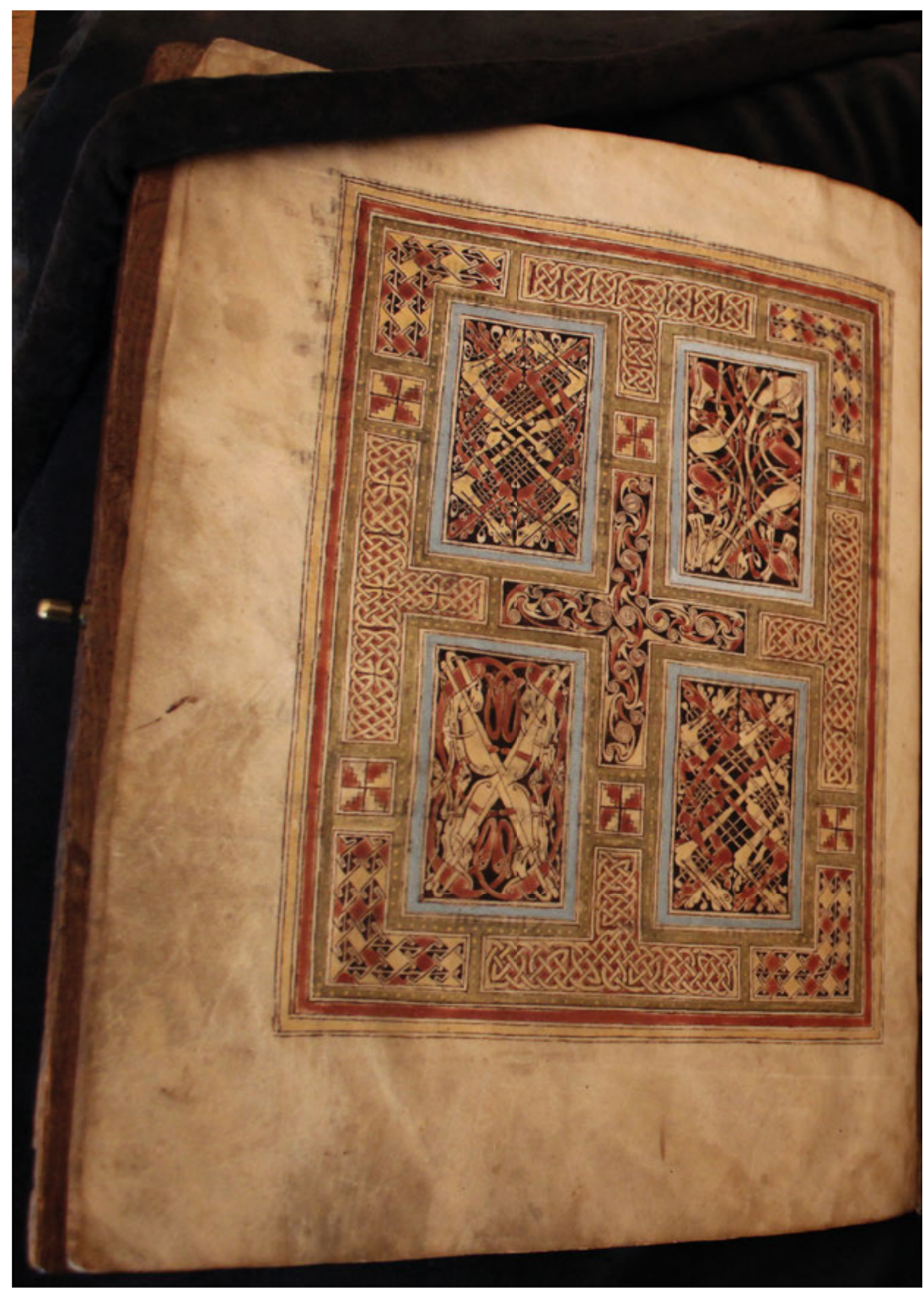




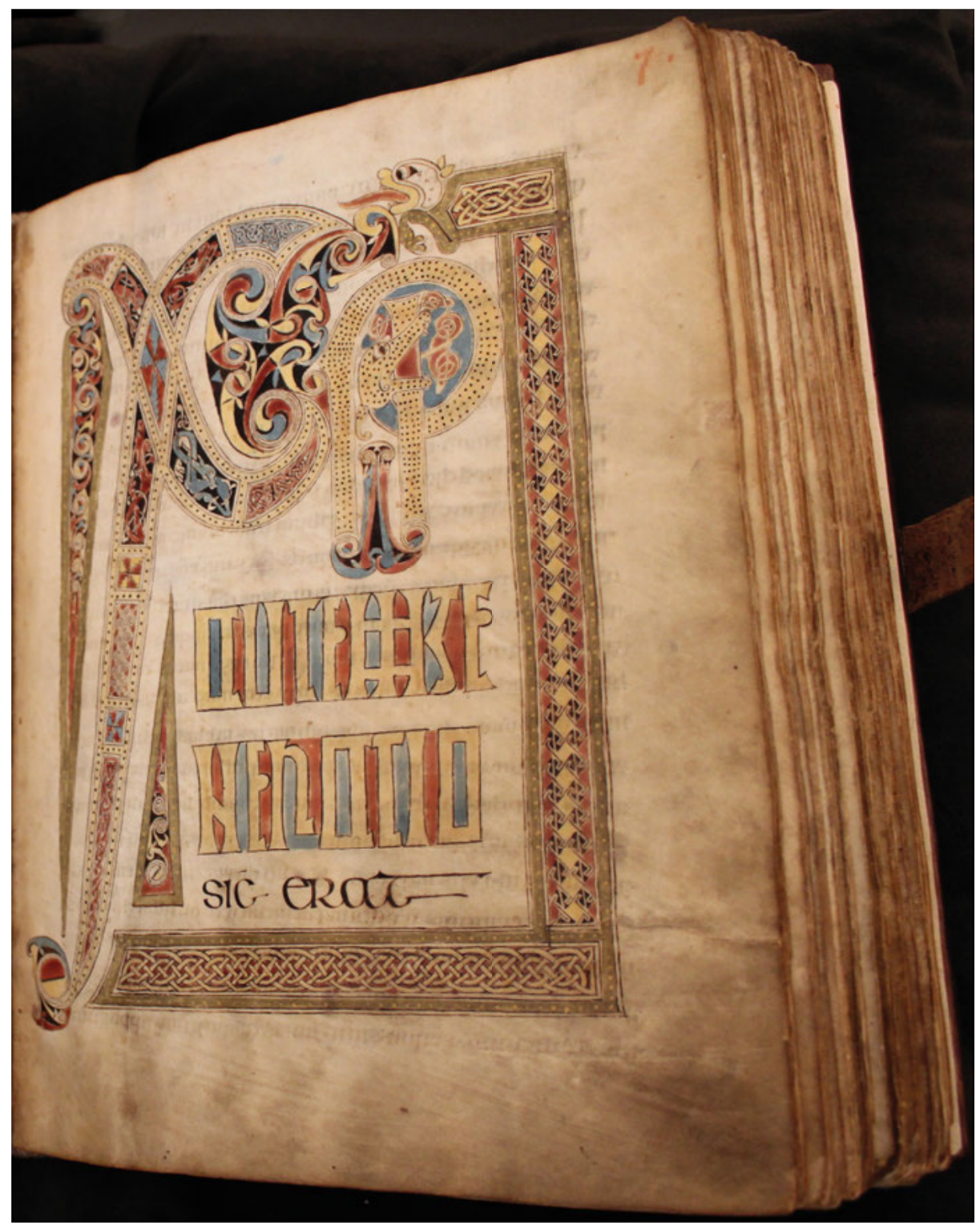

Fig. 3 (both pages): Carpet page and Chi-Rho page, St Gall Gospels, Ireland, mid-eighth century. St Gallen, Stiftsbibliothek, MS 51, pp.6-7. 


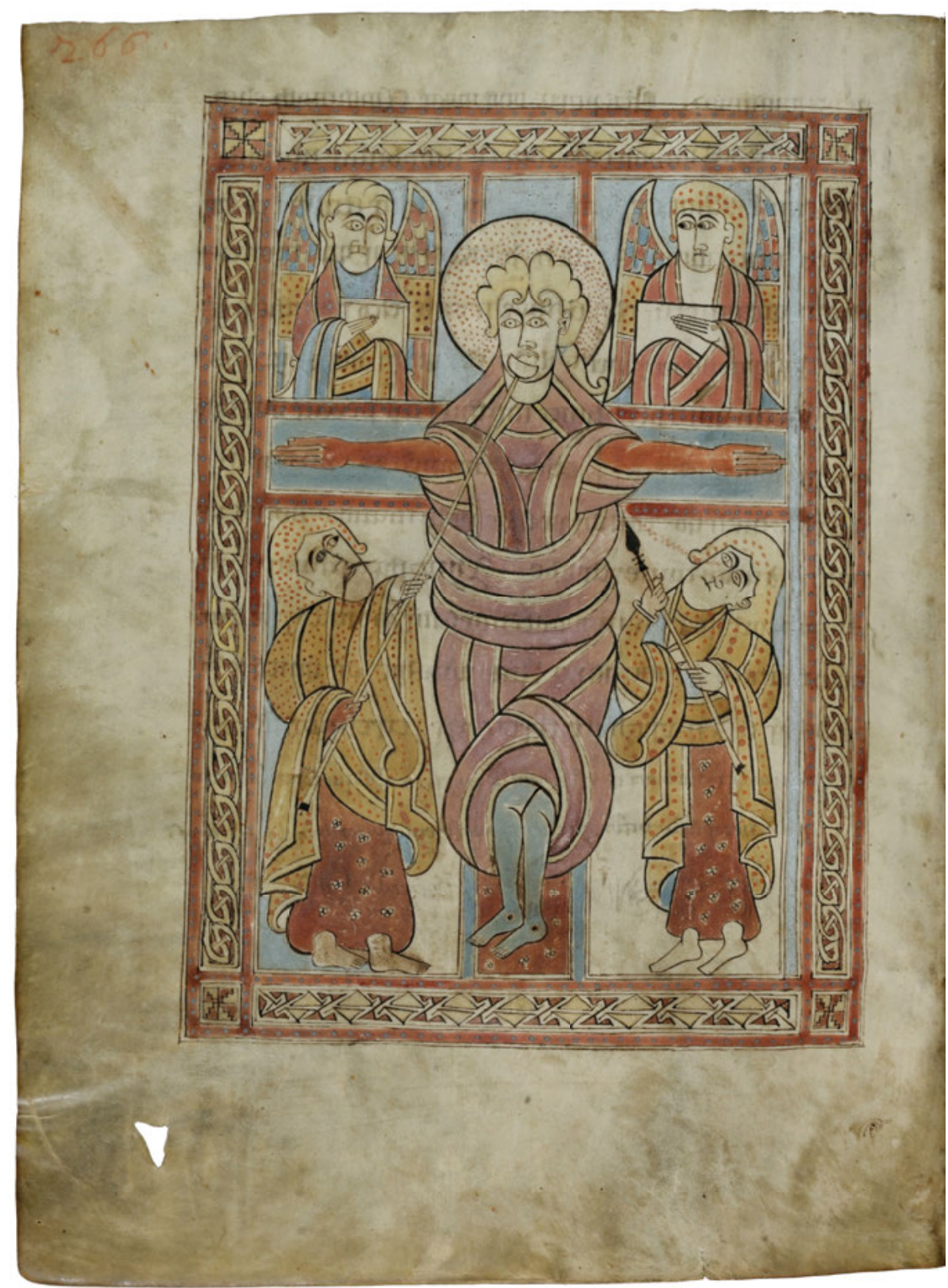




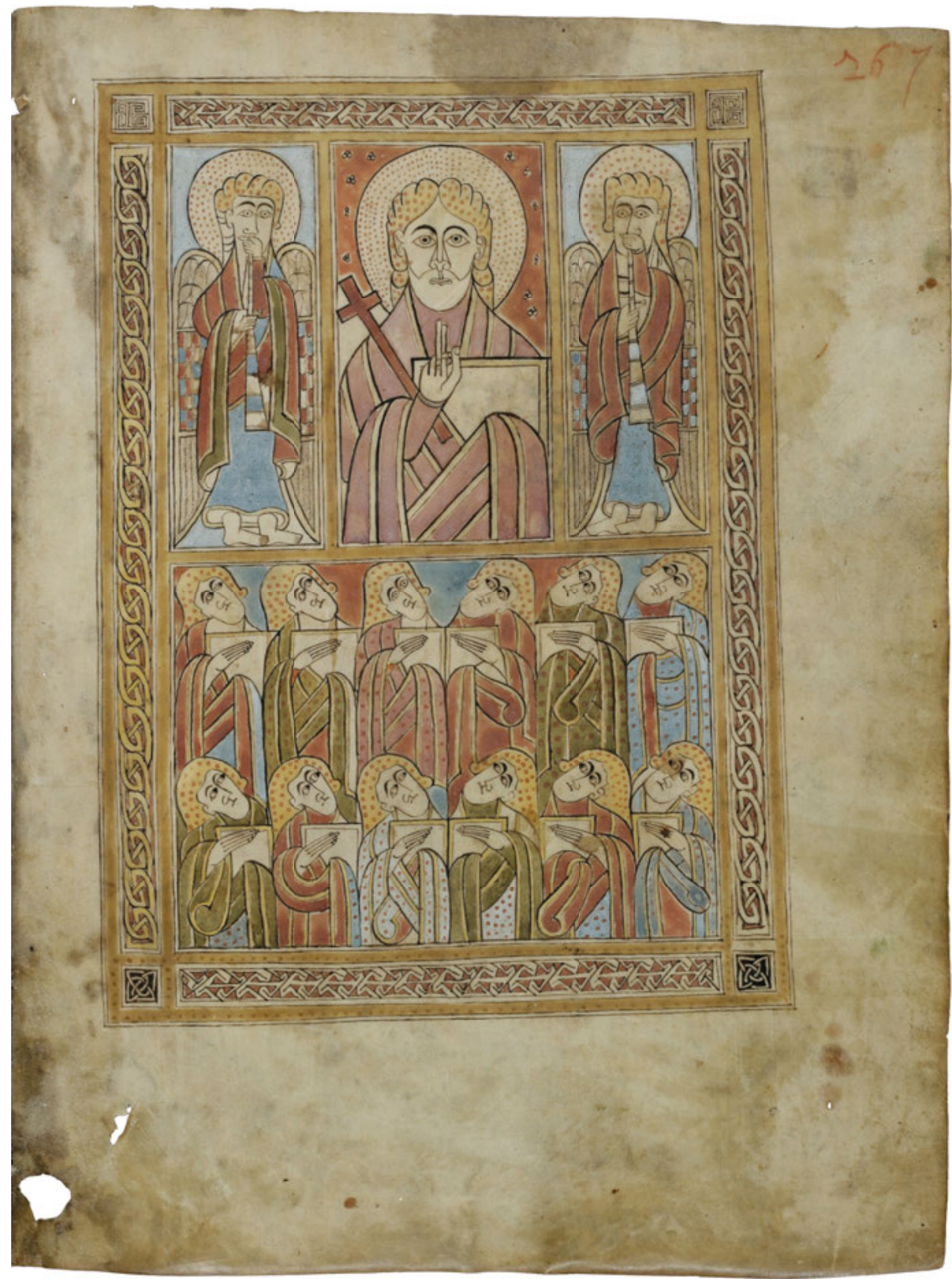

Fig. 4 (both pages): Crucifixion and Second Coming/ Last Judgement, St Gall Gospels, Ireland, mideighth century. St Gallen, Stiftsbibliothek, MS 51, pp. 266-267. 


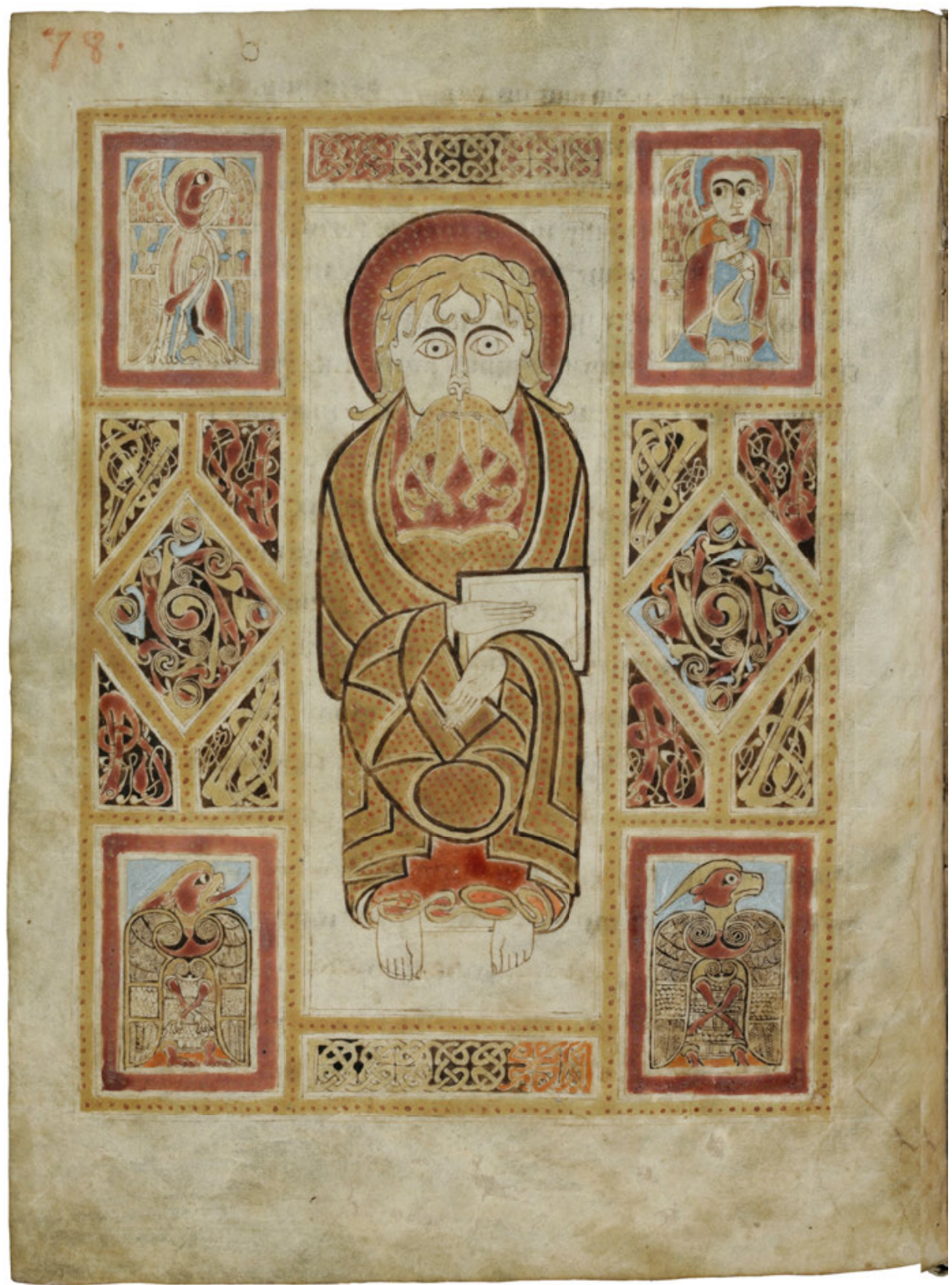




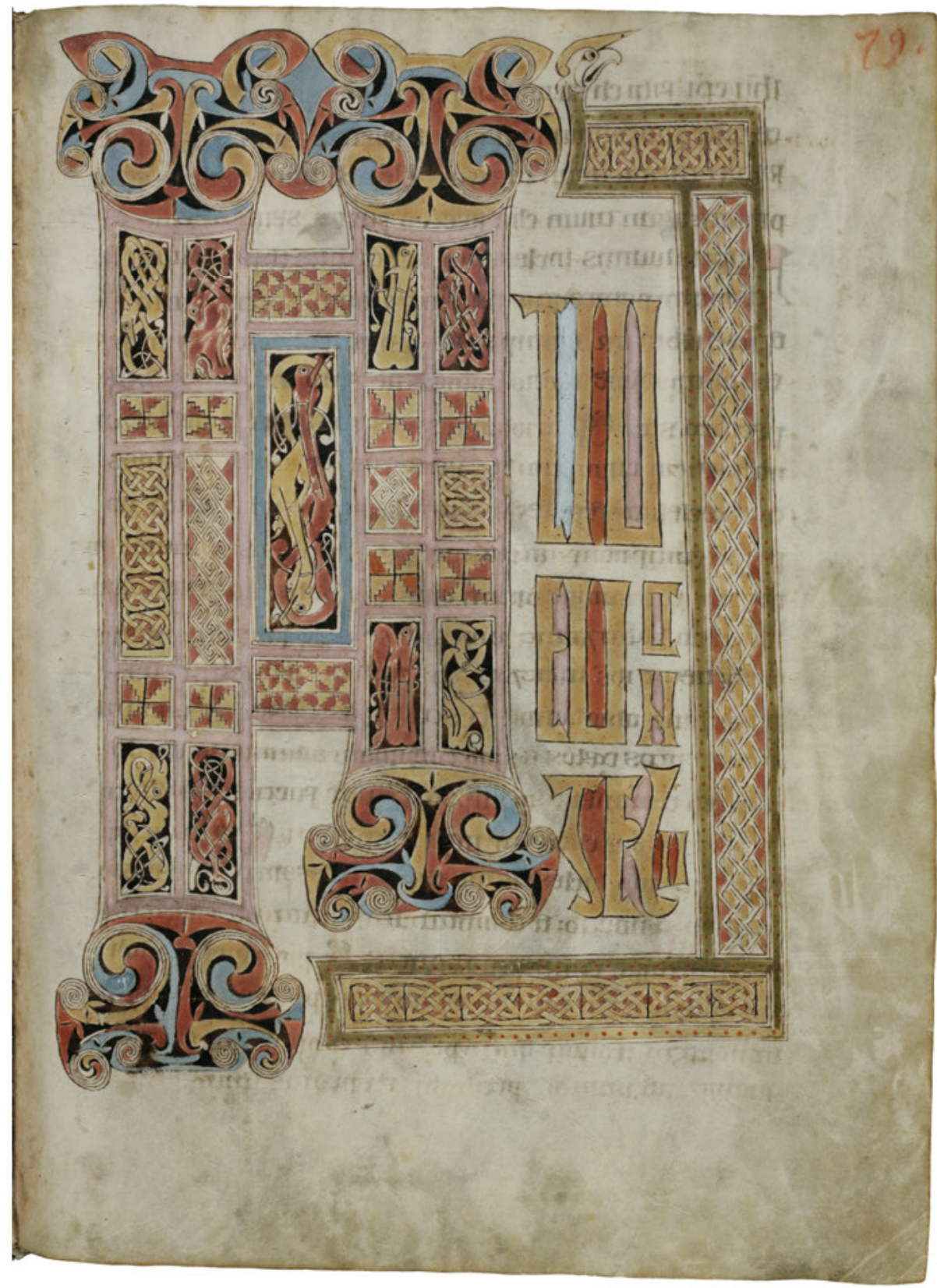

Fig. 5 (both pages): Opening for St Mark's gospel, St Gall Gospels, Ireland, mid-eighth century. St Gallen, Stiftsbibliothek, MS 51, pp.78-79. 
In the St Gall Gospels, this is evident in the layout and distinct graphic rendering of the first three openings. ${ }^{31}$ Both page 4 and page 5 have been ruled for a regular 25 lines of text. On the right, however, the genealogy stops short at line 19, followed by the word finit and a scribe's statement two lines below, both elements commonly found at the end of a text and similar to the treatment of other text endings in the manuscript. ${ }^{32}$ Meticulous planning is also evident at the genealogy in Luke, which like that in Matthew starts on a new page and has a columnar arrangement with red scrolling, though here in contrast to Matthew the columns are read vertically and thus scrolling as a signal of linearity is significant only on a visual rather than a semiotic level (Lk. 3,23-4,4 at p. 140).

While the St Gall Gospels contain interlace panels in frames and monogrammatic letters, the interlace patterns chosen are not complex or compelling, making full use of motifs such as closed circuit and ring motifs that give the impression of interlace without in fact being true interlace. We get an idea of the importance of the interlace principle, on the other hand, in the way it is turned into a central motif in the last miniature: In what has been interpreted as a typical Insular mannerism, an extreme application of ornament, the four fingers of Christ's right hand in the Second Coming miniature have been interlaced (Fig. 4). ${ }^{33}$ In the most simple and effective way, this motif epitomizes the aesthetic and structural theme of the manuscript, a four-strand interlace pattern, the different formulations and semantics of which can be pursued on several levels.

On the opposite page, the Crucifixion miniature shows Christ in a sleeveless garment which consists of four strands of ribbon folds looped around his body, a reference to the four gospels. ${ }^{34}$ As Jennifer O'Reilly has observed, the folds reveal the shape of a lozenge on his chest. ${ }^{35}$ This cosmological symbol of the tetragonus mundi

31 The extant manuscripts suggest that there was no established convention for indicating the unified and autonomous status of the genealogy in graphic and material terms, as other Insular gospel books vary in their ways of singling out this passage: The Lindisfarne Gospels (London, British Library, Cotton MS Nero D.iv) similarly reserve one full opening for Matt. 1,1-17 (fols. 27v-28r), and the incipit for Matthew's gospel reads Incipit evangelii genelogia mathei (fol.27r); in the Macregol Gospels (Oxford, Bodleian Library, MS Auct. D.2.19) Matt. 1,1-2,7 is framed (fols.1v-3r); in the Cutbercht Gospels (Wien, Österreichische Nationalbibliothek, MS 1224) the genealogy (fols. 17v-18r) precedes the portrait of Matthew and the canon tables. In the Book of Dimma it is on a framed page and limited to the left column, the right beginning with the Chi-Rho (Dublin, Trinitiy College, MS 59, p. 2).

$32 \mathrm{D}[$ e]o quantum queo gratias ago meo. In a comparison drawn with München, Bayerische Staatsbibliothek MS Clm 14080, Bernhard Bischoff designated this statement as Insular: Bischoff 1974, 184. 33 Similar evidence of the interlace principle can also be seen in the c. 1000 Southampton Psalter, where the pole with the sponge soaked in vinegar is laced through Stephaton's own brow (Cambridge, St John's College MS C9 (59), fol. 35v; Alexander 1978 cat. no. 74, 88, fig. 351). For a discussion of the way in which these kinds of instances have been interpreted by scholars and the human figure as ornament in Insular manuscript, see Henderson 2008, 33-37.

34 O’Reilly 2013, 52-82.

35 O’Reilly 2013, 64. 


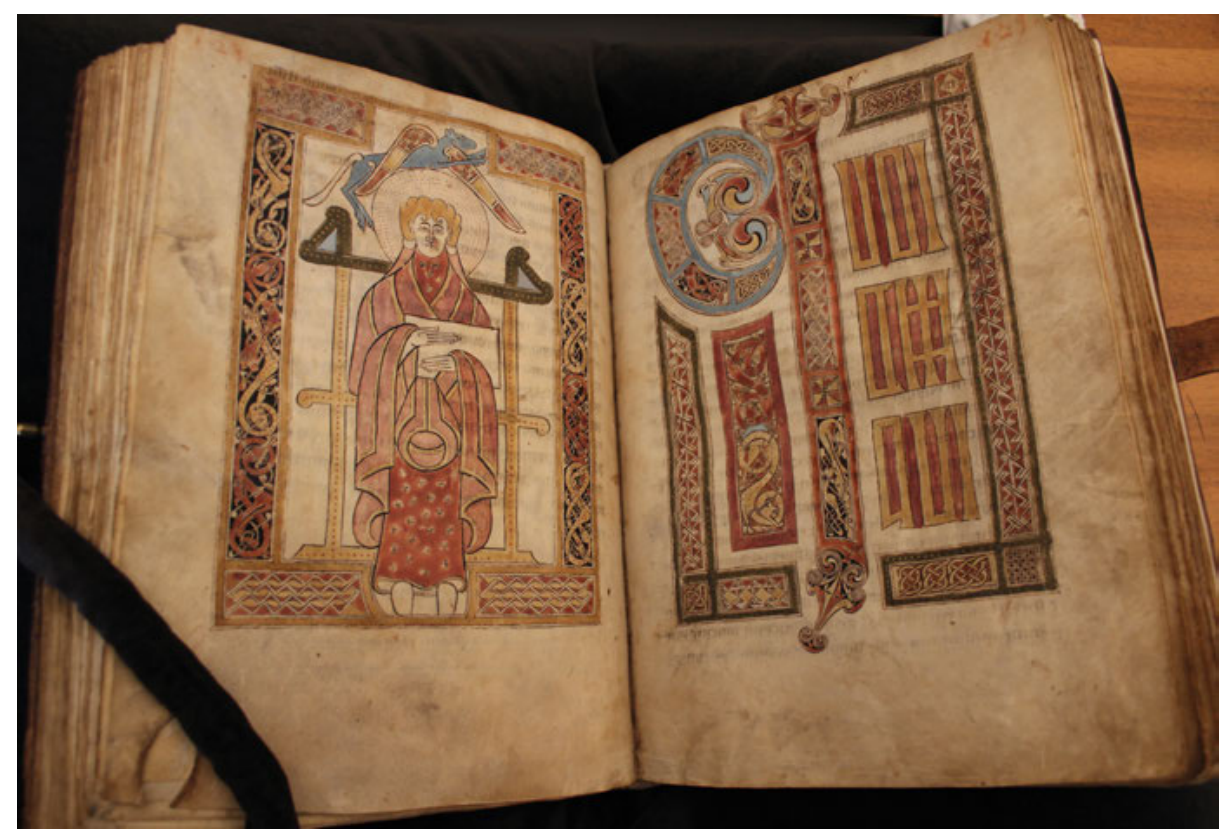

Fig. 6: Opening for St Luke's gospel, St Gall Gospels, Ireland, mid-eighth century. St Gallen, Stiftsbibliothek, MS 51, pp.128-129.

or four-fold world signifies Christ as divine Creator-Logos in a Christian context, used in monogrammatic letters, frames, images and diagrams in Insular and Continental manuscripts. ${ }^{36}$ The lozenge turns up in prominent contexts on two previous pages of the manuscript: at the centre of the letter Chi in the monogram of Christ (p.7; see above Fig. 3), and twice in the frame for the portrait of Mark (Fig.5). In the frame for Mark, the lozenge is a panel filled with trumpet spiral ornament which vertically connects the Evangelist symbols on either side of the frame into pairs, Mark and John on the left and Matthew and Luke on the right. ${ }^{37}$ Significantly, in the Crucifixion it is the four strands of folds which reveal the lozenge shape on Christ's chest, meaning that the theme of incarnation is connected with that of revelation through the fourfold gospel.

The groupings of the evangelist symbols in Mark's frame correspond to two different iconographical types of author portrait used for the evangelist portraits: Mark and John are full-length standing figures that have been fitted into the very tall space between wide double-panel frames, while Matthew and Luke are shown sitting on bar thrones and their surrounding space is enlarged further on the vertical axis by

36 On the tetragonus mundi in an Insular context: O’Reilly 1998, 80-94. On Carolingian examples in manuscript illumination and on coins: Kessler 2015, 39-52.

37 O'Reilly comments on the parallel between the lozenge in the Crucifixion and the Chi-Rho page, but does not mention the connection to the Mark portrait: O’Reilly 2013, 64. 


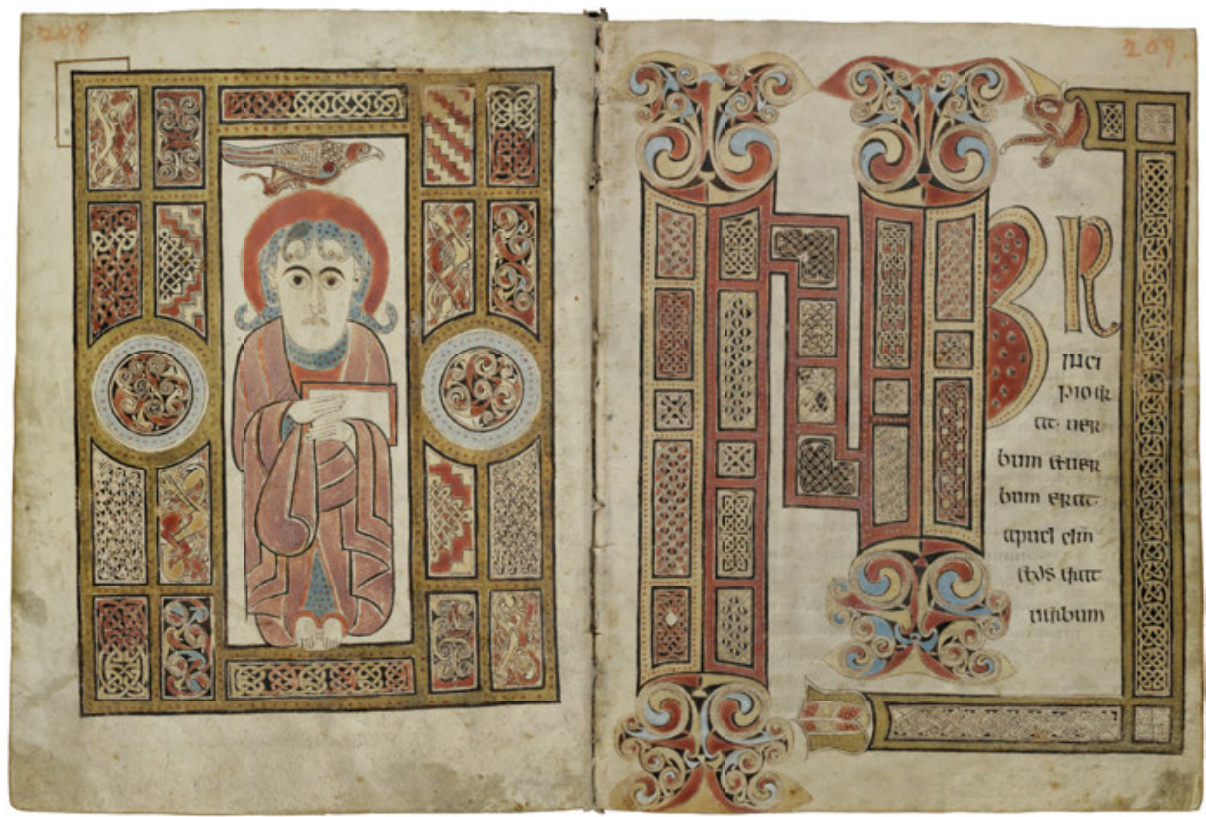

Fig. 7: Opening for St John's gospel, St Gall Gospels, Ireland, mid-eighth century. St Gallen, Stiftsbibliothek, MS 51, pp. 208-209.

the recesses that have been let into the frame for the symbols and the feet of the evangelists (see Fig. 1; Fig. 6). In this regard, St Gallen 51 is part of a tradition of visually pairing evangelists in Insular gospel books, though it is generally more usual to find the apostles Matthew and John associated, drawing on and referring to the emphasis on the Word turned flesh found in the beginning of these two gospel texts. ${ }^{38}$ Here we have Mark and John paired, however, and as I have argued, the reason might be fundamentally graphic rather than scriptural or exegetical (Fig. 7). ${ }^{39}$

The geometric principles underlying the designs for Insular art and especially manuscripts have been demonstrated in several ways. In a 1990 article on the geometry of the St Gall Gospels, Robert Stevick was able to demonstrate that the structure for the figures, especially the position of the large haloes was "derived by geometrical methods from the frames that enclose them," and that therefore the frames were plotted first, followed by the figures. ${ }^{40}$ Taking into account this derivational principle of composition, and the aesthetic priority awarded to the opening, a strong correspondence between the monogrammatic initials and the miniature's frame opposite

38 Cf. O’Reilly 2011, 189.

39 Bawden 2017, see 147-152 for the argument integrated in the following paragraph with a different emphasis.

40 Stevick 1990, 169. 


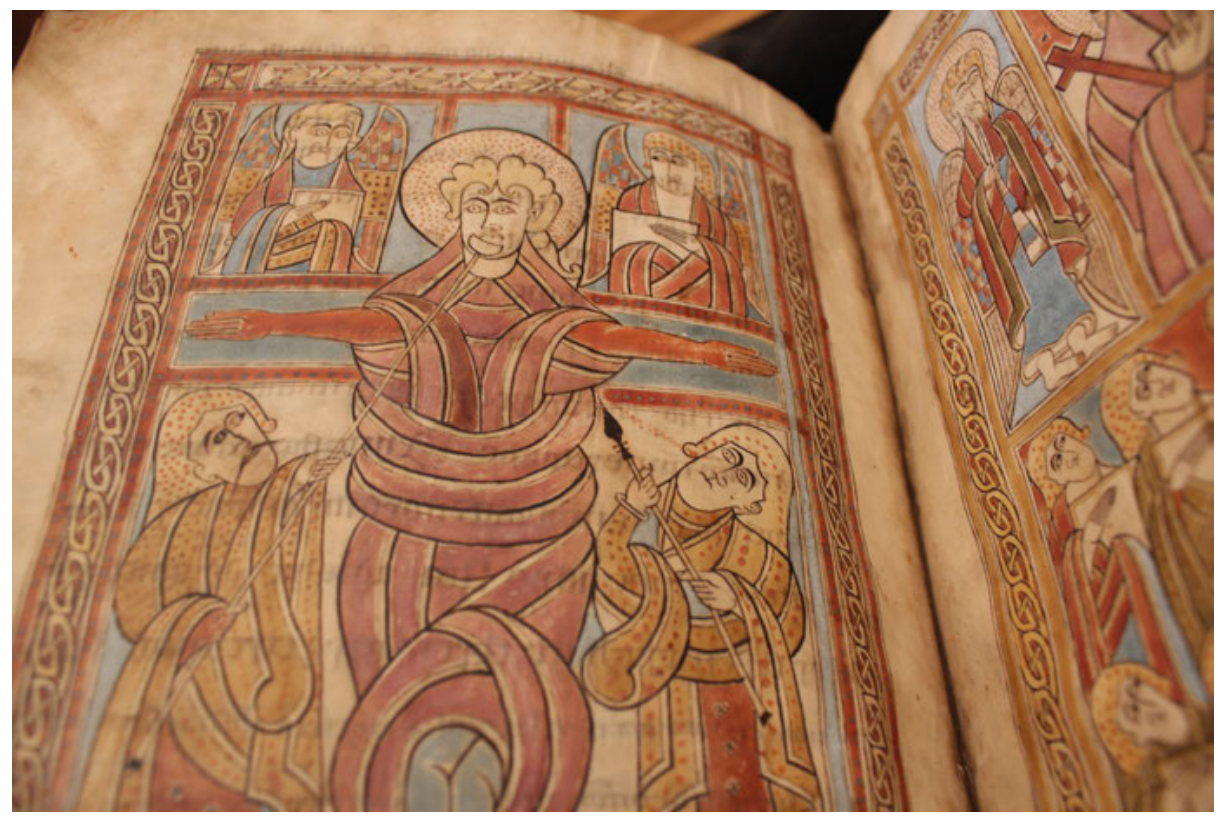

Fig. 8: Detail of Crucifixion, St Gall Gospels, Ireland, mid-eighth century. St Gallen, Stiftsbibliothek, MS 51, p. 266.

in the case of Mark and John in particular is significant. The monograms introducing the beginnings of the gospel text of Mark and John are similar in shape. Moreover, in St Gallen 51 the I/N/I and I/N/P ligatures have been rendered in a way well established in early Insular manuscripts, by attaching the $\mathrm{N}$ to the letters on either side of it, effectively pairing four letter shafts and singling out a central connecting panel, the horizontal bar of the $\mathrm{N}$ derived from Insular half-uncial. ${ }^{41}$ In the monogram of Mark, correspondences between the initial ligature and the miniature concern the distribution of ornament and relative size (see Fig. 5 above). Panels with a black background and zoomorphic ornament occupy the four corners of the monogram and its centre on page 79 in the same way as the Evangelists' symbols are grouped around the central portrait of Mark in the miniature on page 78, so that panels filled with figures on the left correspond to panels filled with zoomorphic ornament on the right. In terms of measurements, this equivalence is reversed: The corner panels are wider than the central panel in the initial ligature, in proportion to the way that the central panel of the miniature is wider than the corner panels containing the symbols. While this is not a true topological equivalence in the mathematical sense, it is evident that it works in a similar way. The kind of spatial concept or category which applies here is one that considers surface relations between neighbouring elements and fields. It is

41 Lindisfarne Gospels, Book of Kells, Book of Armagh. 
at the same time quite distinct from other interests in spatial extension relative to the surface area of the page, namely a primarily 'typographic' concern with layout, and an interest in the conventionally derived semantics or rhetoric of the page, both of which use the page as benchmark. ${ }^{42}$ In the St Gall Gospels, the page is a contingent factor.Patterns therefore form across pages or throughout the book: Visually, and in terms of their iconographical types, the sequence of evangelists presents the shape of a twist, with the design established by Matthew giving way to that of Mark, returning to that established by Matthew with Luke, and John repeating that of Mark.

The cognitive conception of the particular geometric principle of composition was applied to miniature and initial ligature alike, even if actual prickmarks and drypoint lines only remain visible in the miniature pages. This can be seen most clearly in the Matthew portrait page which has a central line running through the figure on the vertical axis (see Fig. 1 above). An exception to the privileging of the frame over the figure reconstructed by Stevick occurs in the Crucifixion miniature (see Fig. 4 above). The preceding text page, the reverse of the Crucifixion miniature, shows that the figure of Christ has been strongly incised in dry point. The outline for the figure includes the eyes, folds of the garments, toes and fingers and the lock of hair at one side of Christ's neck, more comprehensive and prominent than the lines for the frame and the figures of Longinus and Stephaton. The only dry point design otherwise still visible in the figural programme of the manuscript is the symbol of the eagle above John, which according to the outline which only details the beak and head, was planned to be placed slightly further to the right (see Fig. 7 above). This special treatment most likely has a practical explanation. As the parallel to the plotting lines shows, drypoint was reserved for stages of the design that were important to get right, so that the preliminary drypoint sketches for the figure of Christ and the eagle of John seems to be a comment on their exceptionality.

The Crucifixion miniature has probably the oldest depiction of the apocryphal story that blood from Christ's wound healed the spear-bearer Longinus of his blindness. ${ }^{43}$ There is a wavy line of watery red flowing from Christ's side into Longinus' right eye which is shown with a round pupil as already healed and seeing in contrast to his left eye which is rendered as an unseeing slit (Fig. 8). The artistic rendering of the flow of blood is conspicuous: It issues from between the loops of the garment at Christ's armpit as a wavy line which in the context of this manuscript recalls the red scrolling at the genealogy of Christ (Mat. 1,1-17 at pp.4-5, see Fig. 2 above; and Lk. 3,23-4,4 at p.140), but is different in shape and not executed with a quill. Whether the waves are meant to ensure visibility, indicate the large amount of blood pulsing out of the wound or whether this should simply be understood as an attempt to stay

42 On the former, see: Gumbert 1993. On the latter: Goehring 2013, 85 (“spatial rhetoric"); Leson 2014 ("spatial semantics").

43 McNamara 2001, 199. 
within the overall ornamental aesthetic, must remain open. Regardless of questions of meaning and style, we can note, however, that the wavy line recalls graphic elements of script such as line fillers, representing another instance of the intermingling of domains of script and image. The wavy line must have been drawn before larger areas of colour were filled in, because it stems the flow of red paint in the frame bar of the cross, leaving a tiny area of reserve parchment at Christ's armpit and as a result associating the dark red/purple pigment used throughout the volume for elements of script and miniatures with blood. ${ }^{44}$ As O'Reilly and Martin McNamara have shown, the inclusion of this story of healing draws attention to different types of bodily or spiritual sight and understanding. McNamara notes that in the St Gallen $51 \mathrm{manu}$ script, Matthew's gospel contains an interpolation which introduces the opening of Christ's side into this gospel in addition to those of John and Luke, and O'Reilly has shown this to be based on an early Greek harmonizing tradition. ${ }^{45}$ The importance of the scene is therefore evident in text and image alike.

The Second Coming on the following page continues the theme of sight. All twelve apostles apart from one lift their heads and elevate their gazes towards Christ. None of them are identifiable, as they all hold books to their chest and have the same hair and draped garments. The third apostle from the left in the upper row, however, has eyes that resemble those of the angels above, and therefore rather than directing his gaze towards Christ he appears to be looking out of the picture (see Fig. 4 above). ${ }^{46}$ While types had been established for a few of the apostles by the eighth century, the lack of attributes and details in the St Gall Gospels means that comparison with other examples is unlikely to help. A detail which has not been noted before is that the mantle worn by the third apostle is the only one that is of the same pink colour as Christ's, both above and in the Crucifixion image opposite. In addition, all evangelists apart from Mark wear pink, so this was evidently a colour invested with significance. ${ }^{47}$

44 Cf. the way the cross in Christ's hand on the opposite page stems the red paint used for the background in this panel. The identity of the pigments used has not been analysed to my knowledge, but different shades of colour between light red, dark red and purple can be empirically observed. The switch to a new batch is evident occasionally in the text, where the counter spaces of verse initials are highlighted throughout in red and yellow, and the red is more or less orange in appearance, and has oxidised to a greater or lesser extent (i.e. presumably minium and massicot). The dark red used for the cross and the arms of Christ in the Crucifixion miniature is one that here and in other miniatures has pooled noticeably. Generally, pigments seem coherent with those analysed in other Insular manuscripts. See Beeby et al. 2015 with further references.

45 Though the figure of Longinus is wide-spread in medieval iconography, the narrative of his healing might be Irish in origin, as it turns up in the apocryphal tradition (though mainly in texts of a later date). The eighth-century Irish poem of Blathmac mentions it: Blathmac 1964. For detailed accounts of the narrative's genesis, see McNamara 2001; O’Reilly 2013.

46 Discussed briefly by O'Reilly 2013, 69f.

47 It could be inferred, therefore, that the third apostle is meant to be John, whose portrait on p. 208 shows him with enormous eyes. As the theme of spiritual sight is important in this opening, it could also be Thomas. In terms of sequence, this means there would be a parallel to the Trier Gospels from 
On the whole, the manuscript fits into our picture of Insular book illuminators, who refrained from mixing pigments, with pink as the most notable exception here. Pink was used in later Carolingian manuscript illumination to refer to Christ's dual nature, and due to its Christological association in the last opening, this is probably also the case in St Gallen $51 .^{48}$

\section{Conclusion: Interlacing Topologies}

The idea of gospel harmony in the St Gall Gospels is developed visually and graphically, using the material frameworks of the page and opening, as well as the structure of the whole book to forge connections between themes and different places within the manuscript. The interlace principle is therefore evident on several levels of visual argument: Prominent as a motif (Christ's interlaced hand), a textile metaphor for the fourfold gospel (the crucified Christ's colobium), a structuring technique implemented pictorially (evangelist types) to form an alternating pattern or twist brought together by the four-sided lozenge which refers back to the centre, Christ (Mark's frame). The principle concerns script and image alike, not only in the way that Mark's miniature derives its compositional principles from the first three letters of his gospel or at least forges a strong equivalence between author and word graphically, but also in the way that columns and lines of script-i. e. the constructional basics of page layout-are interpreted as strands weaving the genealogy of Christ. While the St Gall Gospels, being such a meticulously planned and therefore homogeneous manuscript, might be a particularly clear example of the way in which the interlace principle can inform the structure of manuscripts, several points might be studied further with regard to other manuscripts. ${ }^{49}$ In order to gain a fuller understanding of whether and how producers and readers/viewers conceived of books as spaces, it seems promising to pay more attention to the structure of manuscripts and the way in which geometry, constructional logic, numerology and visual argument were aligned.

Echternach, where the third of the waist-length figures of the apostles included above the canon tables is designated as Thomas. On comparisons with other groupings, see Netzer 1994, 62-71.

48 On the significance of pink in later Carolingian manuscript illumination, see Kessler 2015, esp. 22-25. 49 A recent article by Heather Pulliam on the canon tables of the Lindisfarne Gospels has drawn attention to the numerology behind the ornamental motifs and their distribution, mediated by colour: Pulliam 2017. Particularly compelling from the perspective of the interlace principle: the diagonal grid structure woven across the columns by the distribution of blue birds: London, British Library, Cotton MS Nero D.iv, fols. 10v-11r: Pulliam 2017, 126, illustration 6.8, table 6.2. 


\section{Bibliography}

Alexander, Jonathan J. G. (1978), Insular Manuscripts 6th-9th Century (A Survey of Manuscripts Illuminated in the British Isles 1), London.

Bawden, Tina (2017), “The Relationship between Letter and Frame in Insular and Carolingian Manuscripts", in: Ildar Garipzanov, Michelle Brown and Benjamin Tilghman (eds.), Visualcy, Literacy, Graphicacy: Graphic Devices and the Early Decorated Book, Woodbridge, 143-162.

Beall, Joanna M. (2010), Interlace and Early Britain, unpublished Ph.D. thesis, Florida State University.

Beeby, Andrew / Duckworth, Andrew/Gameson, Richard / Nicholson, Kate/Clark, R. J. H./ Meehan, B./ Parker, Anthony (2015), "Pigments of the Earliest Northumbrian Manuscripts”, in: Scriptorium 69, 33-59.

Bischoff, Bernhard (1974³), Die südostdeutschen Schreibschulen und Bibliotheken in der Karolingerzeit, pt. 1: Die Bayrischen Diözesen, Wiesbaden.

Blathmac (1964), The Poems of Blathmac Son of Cu Brettan, trans. and ed. by James Carney, Dublin.

Brown, Michelle P. (2007), “The Book as Sacred Space”, in: P. North and J. North (eds.), Sacred Space: House of God, Gate of Heaven, London, 43-63.

Brown, Michelle P. (ed.) (2002), The Lindisfarne Gospels: Cotton MS Nero D.iv der British Library, London/Luzern.

Carruthers, Mary (2008²), The Book of Memory: A Study of Memory in Medieval Culture, Cambridge.

Collins, Samuel W. (2012), The Carolingian Debate over Sacred Space, New York.

Cramp, Rosemary (1991), Grammar of Anglo-Saxon Ornament: A General Introduction to the Corpus of Anglo-Saxon Stone Sculpture, Oxford.

Czock, Miriam (2012), Gottes Haus: Untersuchungen zur Kirche als heiligem Raum von der Spätantike bis ins Frühmittelalter, Berlin.

De Bruyne, Donatien (1920), Préfaces de la Bible latine, Namur.

Duft, J. / Meyer, P. (1954), The Irish Miniatures in the Cathedral Library of Saint Gall, Bern.

Elbern, Victor H. (1971), "Zierseiten in Handschriften des frühen Mittelalters als Zeichen sakraler Abgrenzung”, in: Albert Zimmermann (ed.), Der Begriff der repraesentatio im Mittelalter. Stellvertretung - Symbol - Zeichen - Bild, Berlin, 340-356.

Goehring, Margaret (2013), Space, Place and Ornament: The Function of Landscape in Medieval Manuscript Illumination, Turnhout.

Gumbert, Johann Peter (1993), “'Typography” in the Manuscript Book”, in: The Journal of the Printing Historical Society 22, 5-28.

Henderson, Isabel (2008), "Understanding the Figurative Style and Decorative Program of the Book of Deer", in: Katherine Forsyth (ed.): Studies on the Book of Deer, Dublin 32-66.

S. Hieronimi Presbyteri (1845): Epistola “Ad Heliodorum”, in: Patrologiae cursus completus. Series latina, vol. 22, ed. by Jacques Paul Migne, Paris, Epistula LX, 10.

Huppé, Bernard F. (1970), The Web of Words: Structural Analyses of the Old English Poems "Vainglory", "The Wonder of Creation", "The Dream of the Rood" and "Judith", Albany.

Kessler, Herbert (2015), “Medietas / Mediator and the Geometry of Incarnation”, in: Walter S. Melion and Lee Palmer Wandel (eds.), Image and Incarnation: The Early Modern Doctrine of the Pictorial Image, Leiden / Boston, 17-75.

Kitzinger, Ernst (1993), “Interlace and Icons: Form and Function in Insular Art”, in: Michael Spearman and John Higgitt (eds.), The Age of Migrating Ideas: Early Medieval Art in Northern Britain and Ireland, Edinburgh, 3-15.

Leson, Richard A. (2014), "The Pathways of Salvation: Spatiality and Devotion in the Bute Psalter", in: Gesta 53, 129-154. 
Leyerle, John (1967), “The Interlace Structure of Beowulf”, in: University of Toronto Quarterly 37, 1-17.

Lowe, E. A. (1956), Codices Latini antiquiores, vol. 7, Oxford.

McGurk, Patrick (1961), Latin Gospel Books from A. D. 400 to A. D. 800, Paris.

McNamara, Martin (2001), "Bible Text and Illumination in St Gall Stiftsbibliothek Codex 51, with Special Reference to Longinus in the Crucifixion Scene", in: Mark Redknap, Nancy Edwards, Susan Youngs, Alan Lane and Jeremy Knight (eds.), Pattern and Purpose in Insular Art (Proceedings of the Fourth International Conference on Insular Art Held at the National Museum \& Gallery Cardiff, 3.-6. September 1998), Oxford / Oakville, 191-202.

Netzer, Nancy (1994), Cultural Interplay in the Eighth Century: The Trier Gospels and the Making of a Scriptorium at Echternach, Cambridge.

Neuman de Vegvar, Carol (2007), “Remembering Jerusalem: Architecture and Meaning in Insular Canon Table Arcades", in Rachel Moss (ed.), Making and Meaning in Insular Art (Proceedings of the Fifth International Conference on Insular Art Held at Trinity College Dublin, 25-28 August 2005), Dublin, 242-256.

Nordenfalk, Carl (1938), Die spätantiken Kanontafeln: Kunstgeschichtliche Studien über die eusebianische Evangelien-Konkordanz in den vier ersten Jahrhunderten ihrer Geschichte, 2 vols., Göteborg.

Nordenfalk, Carl (1982), “Canon Tables on Papyrus”, in: Dumbarton Oaks Papers 36, 29-38.

O'Reilly, Jennifer (1998), “Patristic and Insular Traditions of the Evangelists: Exegesis and Iconography”, in: A. M. Luiselli Fadda and E. Ó Carragáin (eds.), Le isole Britanniche e Roma in età romanobarbarica, Roma, 49-94.

O’Reilly, Jennifer (2011), "St. John the Evangelist: Between Two Worlds", in: Colum Hourihane (ed.), Insular and Anglo-Saxon Art and Thought in the Early Medieval Period, Princeton/ University Park, 189-218.

O'Reilly, Jennifer (2013), "Seeing the Crucified Christ: Image and Meaning in Early Irish Manuscript Art”, in: Juliet Mullins, Jenifer Ní Ghrádaigh and Richard Hawtree (eds.), Envisioning Christ on the Cross: Ireland and the Early Medieval West, Dublin, 52-82.

Pulliam, Heather (2017), “Painting by Numbers: The Canon Tables”, in: Richard Gameson (ed.), The Lindisfarne Gospels: New Perspectives, Leiden / Boston, 112-133.

Reudenbach, Bruno (2009), "Der Codex als heiliger Raum. Überlegungen zur Bildausstattung früher Evangelienbücher”, in: S. Müller, L. E. Saurma-Jeltsch and P. Strohschneider (eds.), Codex und Raum, Wiesbaden, 59-84.

Reudenbach Bruno (2015), "Lesung und Präsenz. Überlegungen zu Struktur und Gebrauch frühmittelalterlicher Evangeliare”, in: Rebecca Müller, Anselm Rau and Johanna Scheel (eds.), Theologisches Wissen und die Kunst (Festschrift für Martin Büchsel) (Neue Frankfurter Forschungen zur Kunst 16), Berlin, 345-357.

Stevick, Robert D. (1990), “A Geometer's Art: The Full-Page Illuminations in St. Gallen Stiftsbibliothek Cod. Sang. 51, an Insular Gospels Book of the VIIIth Century", in: Scriptorium 44, 161-92.

\section{Photo Credits}

Fig. 1-8: @ St. Gallen, Stiftsbibliothek, Cod. Sang. 51, p. 2 - Irisches Evangeliar von St. Gallen (Quatuor evangelia).

Fig. 3, 6, 8: Photograph by Tina Bawden, reproduced with kind permission of Stiftsbibliothek, St. Gallen. 